\title{
The Future Demand for Long-term Carers in Germany: Model Calculations for the Federal Länder until 2020
}

\section{Carsten Pohl}

\begin{abstract}
The increase in the birth rate shortfall, at the same time as an increase in life expectancy, will lead to more elderly people living in Germany in future, in both relative and absolute terms. The possible development in the demand for professional long-term carers until 2020 for the individual Federal Länder is illustrated in this essay using model calculations. Because of the differences in demographic change between the Federal Länder, the labour market for long-term care will develop heterogeneously in the federal territory as a whole. The increase in the number of persons in need of long-term care from its current level of 2.25 million to a forecast level of 2.9 million by 2020 will mean that professional long-term care in particular will continue to become more significant in Germany as a whole. The demand for long-term carers (in full-time equivalent posts) could increase from its current level of 561,000 to up to 900,000 by 2020 . The actual development on the professional labour market will however be heavily dependent on the commitment of care-giving relatives. Additionally, possible productivity advances in the provision of long-term care services will play a role, as can be shown in various scenarios of the model calculations.
\end{abstract}

Keywords: labour market for long-term care $\cdot$ demographic change $\cdot$ age structure model calculations

\section{Introduction}

The increase in the birth rate shortfall, at the same time as an increase in life expectancy, will lead to more elderly people living in Germany in future, in both relative and absolute terms. The labour market for long-term care will be particularly affected by this development since, on the one hand, the quantitative increase in the number of elderly people will mean that a much larger number of persons in need of long-term care will live in Germany. On the other hand, the potential of those in 
gainful employment will fall, so that the question will arise as to the adequate care of persons in need of long-term care. The increase in the number of persons in need of long-term care and the fall in the potential supply of labour are now widely divergent between the individual Federal Länder in some cases. The shrinking and ageing of the population has been recorded in the Eastern German Federal Länder for several years, whilst the fall in the population size has only recently set in in the Western Federal Länder. What is more, care arrangements for persons in need of long-term care vary between the Federal Länder. The placement of persons in need of long-term care in institutional facilities or in domestic care is more advanced in some Federal $L a ̈ n d e r$ than in other regions. For this reason, a regional perspective is adopted in order, on the one hand, to show results for the individual Federal Länder and, on the other hand, to work out both similarities and differences between the Länder.

Taking as a basis the future number of persons in need of long-term care in the individual Federal $L a ̈ n d e r$, this article aims to ascertain the possible requirement for long-term carers until 2020. On the basis of the data from the Statistical Offices of the Federation and of the Länder on the number of persons in need of long-term care in the future, it is shown that the type of care received by persons in need of long-term care will be decisive for determining the future demand for professional long-term carers. Domestic care in particular will play a major role, given that a high degree of substitution exists between care-giving relatives and professional longterm care service providers. What is more, the need for long-term carers diminishes if progress is made in the productivity of long-term care. To quantify these effects, various scenarios are taken into account in the model calculations which show both the commitment of the care-giving relatives, and improvements in the ratio between carers/persons in need of long-term care. All in all, the model calculations show that the demand for long-term carers could increase from its current level of 561,000 to up to 900,000 full-time equivalent posts in 2020 .

The following section starts by providing an overview of the current situation on the labour market for long-term care in the Federal Länder. To this end, the providers of long-term care services are compared with persons in need of long-term care in terms of their demand. Then, various scenarios on the possible development of the demand for professional long-term carers are calculated on the basis of the projection of persons in need of long-term care in the individual Federal Länder. The major results of the article are summarised in the last section.

\section{The current situation on the labour market for long-term care in the Federal Länder}

The number of persons in need of long-term care has increased continuously since the introduction of the long-term care statistics. Their number rose by 230,738 in 
the years from 1999 to 2007, from 2.02 million to almost 2.25 million (+11.4\%). ${ }^{1}$ The number of persons in need of long-term care varies considerably between the Federal Länder. In order to restore comparability over Land boundaries, persons in need of long-term care per 10,000 inhabitants are shown (cf. Fig. 1). It then emerges that relatively large numbers of persons in need of long-term care live in the Eastern German Federal Länder in particular. Mecklenburg-Vorpommern, Brandenburg and Sachsen-Anhalt now already have just over 330 people in need of long-term care per 10,000 inhabitants. The number in the large surface-area Länder of Western Germany varies between 220 (Baden-Württemberg) and 300 (Niedersachsen) persons in need of long-term care per 10,000 inhabitants. Seen in absolute terms, the highest numbers of persons in need of long-term care live in Nordrhein-Westfalen, Bayern and Niedersachsen.

From today's figure of 2.25 million persons in need of long-term care in the entire Federal territory, almost 1.03 million, or $46 \%$, are taken care of by relatives. Roughly $22 \%$ of persons in need of long-term care $(504,232)$ are cared for at home by domestic long-term care services, whilst $32 \%$ of all persons in need of long-term care (709,311 persons in need of long-term care) are accommodated in long-term care homes. The type of care changed in the period from 1999 to 2007: The number of care-giving relatives has remained largely constant $(+5,695)$, whilst domestic longterm care services $(+88,943)$ and in particular accommodation in homes $(+136,100)$ have increased considerably. ${ }^{2}$ The nature of care varies significantly between the Länder in some cases. Roughly $40 \%$ of persons in need of long-term care are currently being cared for in institutional facilities in Schleswig-Holstein, whilst the corresponding share in Hessen is only $25 \%$. In contradistinction to this, care by relatives takes on the most significant position in Hessen, at $54 \%$. The corresponding share in Schleswig-Holstein is $39 \%$.

The number of persons in need of long-term care today is compared to that of providers of long-term care services. There were 11,529 domestic long-term care services and 11,029 long-term care homes in 2007. The vast majority of long-term

1 The increase in the number of persons in need of long-term care is not spread equally among all three care categories. Whilst the number of individuals in care categories 2 and 3 remained virtually constant in the time under observation (care category 2: $+2,641$ and care category 3 : $+6,488$; no allocation: $-8,694$ ), almost the entire increase, that is 230,303 persons in need of long-term care, is accounted for by entries in care category 1 (cf. Statistisches Bundesamt 2008). According to the extent of their needs, persons in need of a long-term care are assigned to one of three care levels (1,2 or 3). Assignment to care level 1 requires an extensive need for care and the assignment to care level 2 a strong need for care. Persons with a very strong need for care are assigned to care level 3 (for details see Social Security Code XI for details).

2

The professionalisation of care, that is care provided by domestic long-term care services or accommodation in long-term care homes, hence has a positive correlation with the care category of persons in need of long-term care. Of all persons in need of long-term care in care category 3 $(291,752)$, roughly $50 \%(145,136)$ are cared for in long-term care homes, whilst of all persons in need of long-term care in care category $1(1.15$ million) only roughly $22 \%(253,406)$ are housed in institutions (cf. Statistisches Bundesamt 2008). 
Fig. 1: No. of persons in need of long-term care per 10,000 inhabitants (lefthand scale) and total (right-hand scale) in the Federal Länder in 2007

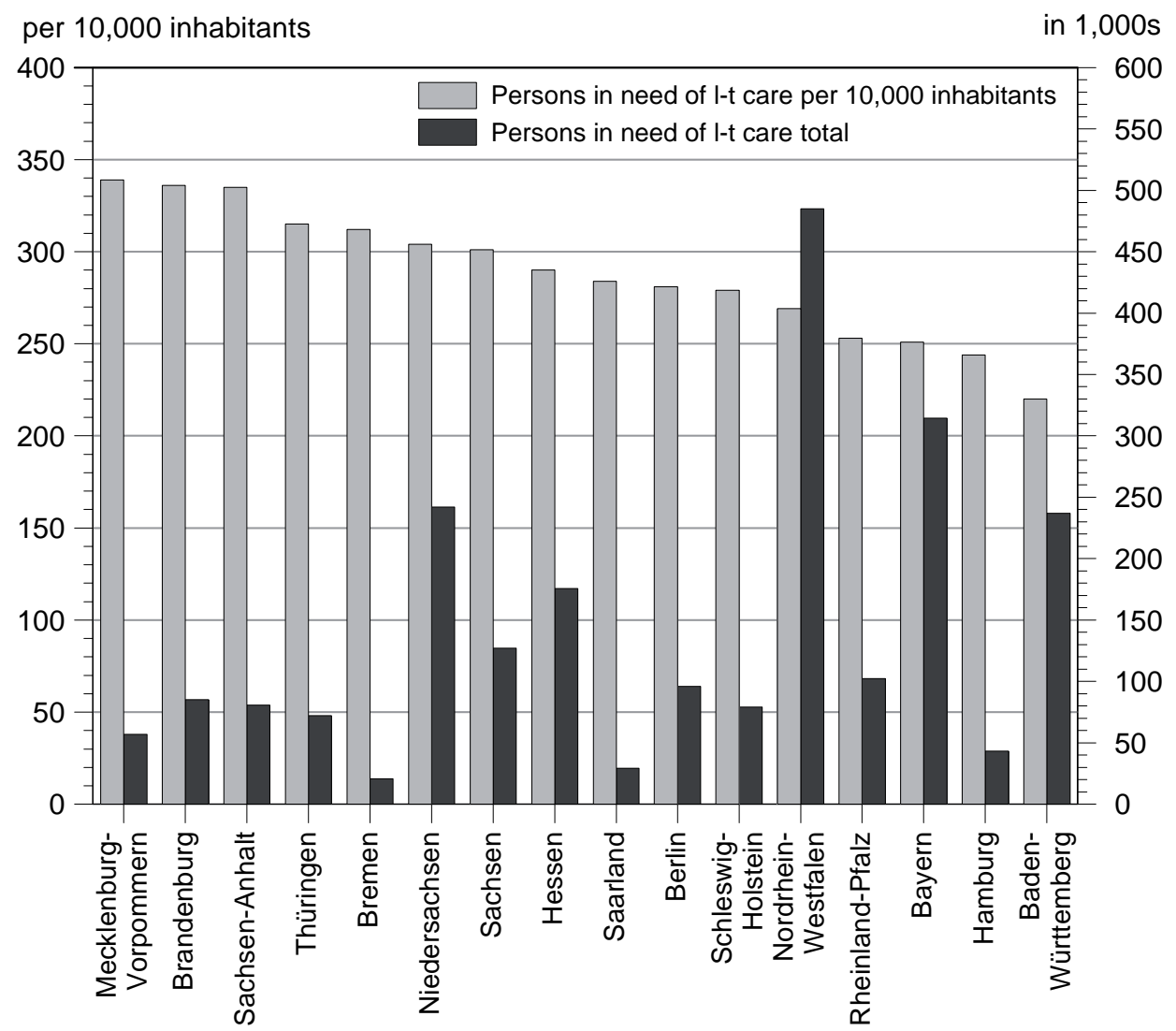

Source: Federal Statistical Office, own calculations.

care services are operated by private institutions $(60 \%)$, followed by charitable institutions with a share of $38 \%$ (cf. Statistisches Bundesamt 2008). The latter group is in turn the most important provider of long-term care homes, and shows a share of roughly $55 \%$. All in all, there were roughly 810,000 employees in the whole area of professional care in 2007 (corresponding to 561,000 staff members in full-time equivalent posts), $80 \%(449,000)$ of whom are accounted for by long-term care homes and $20 \%(112,000)$ by domestic long-term care services. This assessment takes into consideration not only employees in basic long-term care, but also technical and administrative staff. In order to make a comparison possible between the Federal Länder in relation to staff, long-term carers (measured in persons) are converted to full-time equivalent posts (full-time posts). It emerges from the type of the employment relationship that part-timers constitute the lion's share of the staff 
in both domestic long-term care services and long-term care homes. ${ }^{3}$ Part-timers account for $71 \%$ of the staff of domestic long-term care services, whilst the share of part-timers among all staff in long-term care homes is much lower, at $57 \%$. The conversion of the staff into full-time equivalent posts is carried out by considering the actual working hours of the (part-time) staff using data from the long-term care statistics. This reveals the staff numbers in full-time equivalent posts. ${ }^{4}$ Having said that, it would not be expedient to simply compare the full-time equivalent posts at the level of the Federal Länder since - as with the comparison between persons in need of long-term care - effects of scale would influence the result. For this reason, the full-time equivalent posts per person in need of long-term care for each Federal Land were shown. Additionally, the number of full-time equivalent posts differs according to the long-term care arrangement, so that the full-time equivalent posts per person in need of long-term care are shown separately for institutional accommodation and domestic long-term care services (cf. Tab. 1).

Rheinland-Pfalz, Nordrhein-Westfalen and Baden-Württemberg head the institutional domain, with values of more than 0.7 full-time equivalent posts per person in need of long-term care, meaning that the largest number of long-term carers is deployed in these Federal Länder in comparison to the others. In contrast to this, the corresponding rate in Brandenburg, Sachsen-Anhalt and Thüringen is below 0.5 . The rate is also below 0.5 in the two city states Berlin and Hamburg. In other words, almost $30 \%$ fewer full-time equivalents are employed per person in need of long-term care in these Federal Länder in comparison to the top group. The national German average is 0.6 .

The deployment of personnel, that is the number of employees in full-time equivalent posts per person in need of long-term care, also differs from one Federal Land to another when it comes to domestic long-term care services. Whilst domestic long-term care services employ an average of 0.18 full-time equivalents per person in need of long-term care in Brandenburg, Mecklenburg-Vorpommern and SachsenAnhalt, the corresponding value in the city states Berlin (0.34) and Hamburg (0.32) is almost twice as high.

3 The considerable significance attaching to part-time employment is a result of the large share of women in professional long-term care (long-term care homes: $84.7 \%$ and domestic care: $87.6 \%)$.

4 Data from official statistics are used to convert the staff (in persons) into full-time equivalent posts. For our own calculations, first of all the full-time equivalent posts in each Federal Land for 2007 were calculated. To this end, corresponding weights were applied to working hours for all non-full-time posts (part-timers, those in marginal employment, interns, school pupils, trainees, helpers in the voluntary social year, those rendering civil service). The aggregation of the Länder results, finally, leads to the total of full-time equivalent posts in Germany ("bottom up" approach). This leads to a total of roughly 449,000 full-time equivalent posts in the institutional domain and roughly 112,000 full-time equivalent posts in domestic long-term care services, that is a total of almost 561,000 full-time equivalent posts. The Federal Statistical Office has carried out a corresponding calculation regarding full-time equivalent posts for all of Germany, but not for the individual Federal Länder. Almost 575,000 full-time equivalent posts are shown for Germany as a whole for 2007; this corresponds to a deviation of roughly $2.5 \%$ from our own calculations. 
Tab. 1: Number of staff (in full-time equivalent posts) in domestic care and in institutions in 2007

\begin{tabular}{|c|c|c|c|c|c|c|}
\hline & \multicolumn{3}{|c|}{ Institutional long-term care homes } & \multicolumn{3}{|c|}{ Domestic long-term care services } \\
\hline & $\begin{array}{l}\text { Employees } \\
\text { (persons) }\end{array}$ & $\begin{array}{l}\text { Employees in } \\
\text { FTE }\end{array}$ & $\begin{array}{l}\text { FTE per person in } \\
\text { need of } \mathrm{l} \text {-t care }\end{array}$ & $\begin{array}{l}\text { Employees } \\
\text { (persons) }\end{array}$ & $\begin{array}{l}\text { Employees in } \\
\text { FTE }\end{array}$ & $\begin{array}{l}\text { FTE per person in } \\
\text { need of I-t care }\end{array}$ \\
\hline Baden-Württemberg & 73,418 & 60,233 & 0.72 & 24,371 & 11,890 & 0.25 \\
\hline Bayern & 83,499 & 61,606 & 0.59 & 31,721 & 14,258 & 0.20 \\
\hline Berlin & 17,735 & 10,109 & 0.37 & 16,085 & 7,757 & 0.34 \\
\hline Brandenburg & 13,578 & 9,841 & 0.46 & 9,073 & 4,105 & 0.18 \\
\hline Bremen & 4,909 & 4,079 & 0.68 & 3,150 & 1,258 & 0.21 \\
\hline Hamburg & 10,710 & 7,014 & 0.48 & 8,876 & 4,130 & 0.32 \\
\hline Hessen & 36,844 & 27,309 & 0.61 & 16,456 & 8,354 & 0.23 \\
\hline \multicolumn{7}{|l|}{ Mecklenburg- } \\
\hline Vorpommern & 10,420 & 8,319 & 0.50 & 5,496 & 2,548 & 0.18 \\
\hline Niedersachsen & 64,969 & 51,467 & 0.65 & 24,033 & 10,432 & 0.19 \\
\hline Nordrhein-Westfalen & 139,013 & 117,566 & 0.77 & 48,019 & 23,698 & 0.22 \\
\hline Rheinland-Pfalz & 26,523 & 22,982 & 0.78 & 9,467 & 4,901 & 0.25 \\
\hline Saarland & 7,669 & 5,422 & 0.58 & 2,522 & 1,238 & 0.21 \\
\hline Sachsen & 28,156 & 22,446 & 0.52 & 15,096 & 6,976 & 0.21 \\
\hline Sachsen-Anhalt & 15,755 & 11,364 & 0.48 & 7,047 & 3,528 & 0.18 \\
\hline Schleswig-Holstein & 27,038 & 19,230 & 0.60 & 8,264 & 3,687 & 0.22 \\
\hline Thüringen & 13,309 & 9,816 & 0.49 & 6,486 & 3,210 & 0.19 \\
\hline Germany & 573,545 & 448,801 & 0.63 & 236,162 & 111,968 & 0.22 \\
\hline
\end{tabular}

Note: FTE $=$ full-time equivalent posts

Source: Federal Statistical Office, own calculations.

One may not however draw conclusions from the comparison of full-time equivalent posts per person in need of long-term care as to the efficiency/quality of care in the individual Federal Länder. The differences in the deployment of staff might be caused, on the one hand, by better-organised care in those Federal Länder in which fewer staff are deployed. On the other hand, the quality of care in the Federal Länder with a high staff deployment might indeed be much better. Since no data are (yet) available on the quality of care, these hypotheses with regard to greater efficiency or quality in the care of persons in need of long-term care can be neither confirmed nor rejected. ${ }^{5}$

The situation on the labour market for long-term care must currently be regarded as tense, since there are already bottlenecks in the present circumstances. In addition to those staff who are included in the official statistics, there is also "domestic help" - primarily from neighbouring countries in Central and Eastern Europe - working in Germany. The term "domestic help" is misleading in this respect since such individuals as a rule carry out long-term care activities. Depending on the study, the estimates range here from 50,000 to 100,000 illegal employees (Neuhaus et al. 2009). Because of the (growing) shortage of specialists in long-term care, the legislature adopted a statute in mid-2009 which will also permit those leaving school with

5 Cf. Federal Ministry of Health for measures to increase quality in long-term care: http://www. bmg.bund.de/pflege/qualitaetssicherung/wie-erkenne-ich-ein-gutes-heim.html 
a secondary general school qualification to take up training as a (geriatric) nurse. At the beginning of 2009, the Federal Parliament also agreed to have care for the elderly included in the Posted Workers Act (Entsendegesetz), so that there will be a minimum wage in this sector from mid-2010. The collective bargaining commission established by the Federal Ministry of Labour and Social Affairs recommends minimum wages of EUR 8.50 in Western Germany and EUR 7.50 in Eastern Germany (cf. Creutzburg 2010). The wages for staff in basic long-term care are to be increased by 25 Cent in each of 2012 and 2013. The impact of the introduction of a minimum wage in long-term care is currently the subject of controversial discussion. On the one hand, the minimum wage could lead to an increase in the prices for long-term care services if the higher staffing costs are passed on to persons in need of longterm care, so that a larger share of the available income of persons in need of longterm care or of their relatives would have to be spent on long-term care services in the future. On the other hand, it would also be conceivable that the higher costs could not be passed on to persons in need of long-term care because of intensive competition, thus stepping up economic pressure on long-term care providers and increasing the probability of insolvency in this sector, which ultimately could lead to a supply deficit when it comes to long-term care places (Augurzky et al. 2009).

\section{Demographic change and future developments in numbers of persons in need of long-term care}

The number of persons in need of long-term care will be closely linked to future demographic developments. For this reason, it is predominantly the main results of the 12th Coordinated Population Forecast of the Statistisches Bundesamt (2009) which are presented. Because of the falling number of live births and at the same time of the rising number of deaths over time, the fall in the population size will accelerate in the coming years. All in all, the population could fall by $-2.8 \%$ from roughly 82 million in 2007 to 79.882 million in 2020 (scenario lower limit of the "median" population). ${ }^{6}$ The fall in the population size in the Eastern German Federal Länder will be much more rapid: The population of Sachsen-Anhalt will fall by $-13.6 \%$ by 2020 , that of Thüringen by $-11.4 \%$ and of Mecklenburg-Vorpommern by $-9 \%$. By comparison, the decreases in large surface-area Länder of Western Germany will be

6 The 12th Coordinated Population Forecast of the Statistisches Bundesamt (2009) covers the period until 2060. However, the Statistical Offices of the Federation and of the Länder only show the forecasts on persons in need of long-term care until 2020, so that the next ten years are observed in this article. The calculations concerning the future number of persons in need of long-term care here are based on the 11th Coordinated Population Forecast of the Statistisches Bundesamt (2006). 
relatively moderate: Nordrhein-Westfalen will lose $-3.5 \%$ and Baden-Württemberg $-0.4 \%$, whereas in fact a slight increase is calculated for Bayern $(+0.8 \%){ }^{7}$

Whilst the impact of demographic change on the population size as a whole is comparatively moderate, in particular there will be shifts in the age structure which in turn are relevant to the long-term care sector. In $2007,20.4 \%$ of inhabitants in Germany were aged 65 and older (16.729 million). The share of the overall population accounted for by 20 - to 64 -year-olds was $60.6 \%$ (49.655 million), and $19 \%$ (15.619 million) were younger than 20. This structure will also change markedly in the short time until 2020 because of the increasing birth rate shortfall and the rising life expectancy. In the variant median population "lower boundary", the share of those over 65 increases to $23.3 \%$ (18.646 million), corresponding in absolute terms to an increase of roughly 2 million by 2020. Significant differences are found here in turn between the individual Federal Länder. The share of those aged from 65 in 2020 is expected to already be roughly $28 \%$ in Sachsen, Sachsen-Anhalt and Thüringen, whilst in the large surface-area Länder of Western Germany only not quite $22 \%$ of the total population will then be over 64 . Only 13.601 million people below the age of 20 will live in the overall Federal territory in 2020 (falling by 2 million or $-13 \%$ ).

The combination of a fall in the population size and an increase in the share of elderly people in the total population has two consequences for the labour market for long-term care. Firstly, the potential for labour will fall since the size of the working-age population (20- to 64-year-olds) will decrease. Secondly, the number of persons in need of long-term care will considerably increase since more elderly people, and hence potentially more persons in need of long-term care, will live in society. The probability of being in need of long-term care is very closely correlated with age, there being pronounced differences between men and women in some cases. In the age class of 70- to under 75-year-olds, the long-term care rate (prevalence rate), i.e. the number of persons in need of long-term care in this age class, divided by the population in this age class, is almost identical at $4.8 \%$ (men: $4.8 \%$; women: $4.9 \%$ ). The prevalence rate of women rises faster with increasing age than that of men. $8.9 \%$ of men aged 75 - to under 80 -year-olds, but as many as $10.7 \%$ of women, are in need of long-term care. The difference is most pronounced in the age class of 90 -year-olds and older: $38.9 \%$ of men and $68.8 \%$ of women (Statistische Ämter des Bundes und der Länder 2008) are then in need of long-term care.

The Statistische Ämter des Bundes und der Länder (2008) have presented a forecast of persons in need of long-term care at the level of the Federal Länder. Two scenarios were shown for Germany as a whole, whilst for the individual Federal

7 All in all, twelve variants on demographic development are shown, all of these being based on different presumptions regarding fertility, life expectancy and the migration balance. In both "medium" variants, which seen from today's point of view are most realistic, fertility will also continue at 1.4 children per woman. Life expectancy will increase, so that life expectancy for boys and girls who are born in 2060 will have increased by between eight and seven years in comparison to those being born today. The only difference between the two "medium" variants lies in the presumed net immigration, which is however not relevant for the relatively short period until 2020. 
Länder only one variant (the so-called status quo scenario) was calculated up to 2020 , thus forming the basis for further observations. In the status quo scenario at the level of the Federal Länder, the current long-term care rates are transferred to the population in the future, separated by five-year age classes and gender. ${ }^{8}$ Three scenarios are theoretically conceivable for the added lifetime as to the need of longterm care. This need could increase in parallel with the increase in life expectancy if the lifeyears gained are spent in good health. Alternatively, a below- or aboveaverage increase in healthy years would be possible. These last two scenarios mirror the compression and medicalisation hypotheses. More recent empirical studies provide indications of the relative morbidity compression hypothesis, i.e. the overall phase of years spent in illness or long-term care decrease as a share of total life expectancy. ${ }^{9}$ Having said that, the Statistical Offices of the Federation and the Länder did not show any figures for the individual Federal Länder for this scenario. The status quo scenario observed is hence likely to constitute an upper limit for the number of persons in need of long-term care in the future.

The results of the Statistische Ämter des Bundes und der Länder (2008) are contained in Table 2, with 2007 being selected as a reference year. Because of the different age structures in the Federal Länder, the increase in numbers of persons in need of long-term care will also differ. For Germany as a whole, an increase of roughly 650,000 persons in need of long-term care is anticipated to occur by 2020 , reaching almost 2.9 million, corresponding to an increase of roughly $30 \%$ in comparison to 2007.

The increase is generally greater in the Eastern German Federal Länder in general terms, being roughly $40 \%$ in Brandenburg and in Mecklenburg-Vorpommern, for instance. Having said that, a relatively large number of persons in need of longterm care already live in the Eastern German Federal Länder today in comparison to Western Germany, so that the growth rates may provide a distorted picture because of the different starting points. For this reason, the number of persons in need of long-term care per 10,000 inhabitants is shown as well. There will be roughly 364 persons in need of long-term care per 10,000 inhabitants in 2020 in the total Ger-

8 The following example is to make this approach in the calculation clear: $15.6 \%$ of men and $22.2 \%$ of women were in need of long-term care in the age class of 80 - to 85-year-olds in 2007. These gender- and age-specific long-term care rates are kept constant and multiplied with the population in this age class in 2020, so that the new number of persons in need of long-term care is then calculated. Totalling all gender- and age-specific persons in need of long-term care then gives the number of persons in need of long-term care in Germany.

Cf. also Hackmann and Moog (2008a) on the impact of life expectancy on the likelihood of needing long-term care. 
Tab. 2: No. of persons in need of long-term care in the Federal Länder in 2007 and 2020

\begin{tabular}{l|c|c|c|c}
\hline & 2007 & \multicolumn{3}{|c}{2020} \\
\cline { 2 - 5 } & $\begin{array}{c}\text { Persons in need } \\
\text { of I-t care in } \\
1,000 \text { s }\end{array}$ & $\begin{array}{c}\text { Persons in need } \\
\text { of I-t care in } \\
1,000 \text { s }\end{array}$ & $\begin{array}{c}\text { Increase from } \\
2007\end{array}$ & $\begin{array}{c}\text { Persons in need of } \\
\text { I-t care per 10,000 } \\
\text { inhabitants }\end{array}$ \\
\hline Baden-Württemberg & 237 & 320 & $35 \%$ & 299 \\
Bayern & 314 & 417 & $33 \%$ & 330 \\
Berlin & 96 & 128 & $33 \%$ & 376 \\
Brandenburg & 85 & 118 & $39 \%$ & 488 \\
Bremen & 21 & 24 & $18 \%$ & 369 \\
Hamburg & 43 & 52 & $20 \%$ & 282 \\
Hessen & 176 & 215 & $22 \%$ & 362 \\
Mecklenburg-Vorpommern & 57 & 80 & $40 \%$ & 523 \\
Niedersachsen & 242 & 300 & $24 \%$ & 391 \\
Nordrhein-Westfalen & 485 & 614 & $27 \%$ & 354 \\
Rheinland-Pfalz & 102 & 130 & $27 \%$ & 330 \\
Saarland & 29 & 37 & $27 \%$ & 390 \\
Sachsen & 127 & 170 & $33 \%$ & 435 \\
Sachsen-Anhalt & 81 & 106 & $31 \%$ & 508 \\
Schleswig-Holstein & 79 & 104 & $32 \%$ & 371 \\
Thüringen & 72 & 95 & $32 \%$ & 468 \\
Germany & 2,247 & 2,911 & $30 \%$ & 364 \\
\hline
\end{tabular}

Source: Federal Statistical Office, own calculations.

man average, whilst there will be more than 500 persons in need of long-term care in some Eastern German Federal Länder. ${ }^{10}$

In addition to the forecast of persons in need of long-term care at the level of the Federal Länder in total, it is decisive for the professional labour market for longterm care how persons in need of long-term care are distributed in future among the various long-term care arrangements, that is among care by relatives, domestic long-term care services and long-term care homes. Since these calculations are not carried out by the Statistical Offices of the Federation and the Länder, two separate scenarios were developed. A distinction is made here between a base scenario and an alternative scenario.

It is presumed in the base scenario that the distribution of persons in need of long-term care among the various care forms in future corresponds to the distribu-

10 The reasons for the different number of persons in need of long-term care per 10,000 inhabitants and for the increase from 2007 to 2020 vary. They include the differences in the age structure, but also differences in life expectancy between Eastern and Western Germany, and hence, indirectly, the probability of needing long-term care at all. Life expectancy at birth was three years lower in Eastern Germany than in Western Germany at the beginning of the 1990s. Moreover, the remaining life expectancy was also lower, since medical care was not as good in the GDR as it was in the West. These differences have now become slight, but nonetheless exert an impact on the (future) number of persons in need of long-term care. 
Tab. 3: No. of persons in need of long-term care in 2020 by type of care (base scenario; absolute figures in 1,000s; change from 2007 to 2020)

\begin{tabular}{lrrrrrrr}
\hline & \multicolumn{2}{c}{ At home } & \multicolumn{2}{c}{ Domestic care } & \multicolumn{2}{c}{ Institutional care } & Total \\
& absolute & change & absolute & change & absolute & change \\
\hline Baden-Württemberg & 143 & $35 \%$ & 66 & $41 \%$ & 111 & $33 \%$ & 320 \\
Bayern & 190 & $36 \%$ & 88 & $26 \%$ & 139 & $33 \%$ & 417 \\
Berlin & 62 & $34 \%$ & 30 & $33 \%$ & 36 & $32 \%$ & 128 \\
Brandenburg & 54 & $31 \%$ & 33 & $45 \%$ & 32 & $49 \%$ & 118 \\
Bremen & 10 & $20 \%$ & 7 & $20 \%$ & 7 & $15 \%$ & 24 \\
Hamburg & 19 & $21 \%$ & 15 & $20 \%$ & 17 & $17 \%$ & 52 \\
Hessen & 118 & $23 \%$ & 41 & $16 \%$ & 56 & $25 \%$ & 215 \\
Mecklenburg-Vorpommern & 36 & $38 \%$ & 19 & $39 \%$ & 24 & $43 \%$ & 80 \\
Niedersachsen & 132 & $23 \%$ & 68 & $22 \%$ & 100 & $26 \%$ & 300 \\
Nordrhein-Westfalen & 285 & $27 \%$ & 132 & $23 \%$ & 198 & $29 \%$ & 614 \\
Rheinland-Pfalz & 66 & $24 \%$ & 26 & $29 \%$ & 38 & $30 \%$ & 130 \\
Saarland & 18 & $28 \%$ & 7 & $25 \%$ & 12 & $26 \%$ & 37 \\
Sachsen & 69 & $35 \%$ & 44 & $35 \%$ & 56 & $31 \%$ & 170 \\
Sachsen-Anhalt & 49 & $32 \%$ & 26 & $31 \%$ & 31 & $31 \%$ & 106 \\
Schleswig-Holstein & 41 & $35 \%$ & 21 & $29 \%$ & 42 & $30 \%$ & 104 \\
Thüringen & 47 & $32 \%$ & 22 & $31 \%$ & 26 & $31 \%$ & 95 \\
Germany & 1,339 & $30 \%$ & 646 & $28 \%$ & 925 & $30 \%$ & 2,911 \\
\hline
\end{tabular}

Source: own calculations.

tion of $2005 .{ }^{11}$ In other words, all forms of care will cater for more persons in need of long-term care in future. Table 3 presents the results of the base scenario. All in all, the number of persons in need of long-term care who are cared for at home totals roughly 1.339 million in 2020. Here, differences in the increases between the Federal Länder appear. The increase is highest in Mecklenburg-Vorpommern, at $38 \%$, whilst the increase is only $20 \%$ in Bremen. The number of persons in need of long-term care who are taken care of by domestic services increases to a total of 646,000 , and the number of persons in need of long-term care in institutional facilities increases to 925,000 .

The base scenario centres on the presumption that the number of care-giving relatives will also continue to increase in future. This presumption is however to be judged critically since a large number of studies suggest the conclusion that the supply of care-giving relatives will not increase in future, but will in fact fall slight-

11 The distribution of persons in need of long-term care among the individual care forms of 2005 (and not of 2007) is selected since from the present view one may presume that fewer relatives will (be able to) take care of their relatives in need of long-term care in future. The consequence of this presumption is that the increase in care provided by relatives will increase more slowly in future than if the distribution of 2007 had been presumed. The share of care-giving relatives among care provided to persons in need of long-term care was roughly one half percentage point higher in 2007 than the share in 2005. 
Iy. ${ }^{12}$ This is a result, firstly, of the low fertility in recent decades and of the increase in childlessness, so that the family care potential in Germany is falling as a whole. Secondly, the geographical distance between parents and children has increased in recent years, resulting in a reduction in family care (Schnabe/ 2007 and Konrad et al. 2002). Thirdly, a further increase in gainful employment has a slowing impact on the potential for family care. Since for years there has been a trend towards higher educational qualifications among both men and women, and the highly-qualified also have a higher employment rate, this results in a fall in family care (women so far account for roughly $3 / 4$ of first main carers). ${ }^{13}$ What is more, the increase in the statutory age limit for the statutory old-age pension can be assumed to mean that employees will be in employment for longer. Fourthly, moreover, there is a trend towards less established partnerships among the elderly, so that not only care by one's own children, but also care by partners could reduce (Keck/Saraceno 2009). Fifthly, the Population Forecasts of the Federal Statistical Office show that a pronounced increase will be observed among the very old in particular. These are most likely to become in need of long-term care and to reach the upper care category, so that domestic and institutional care will take on greater significance. In today's terms, these reasons therefore suggest that care provided by care-giving relatives will not continue to increase in future, but that it will indeed fall slightly. ${ }^{14}$

For this reason, an alternative scenario is calculated in which the level of caregiving relatives is set at that of $2005 .{ }^{15}$ The total number of persons in need of long-term care corresponds precisely to the status quo scenario of the Statistical Offices of the Federation and of the Länder (or the base scenario), but the distribution among the individual care forms differs. The number of persons in need of long-term care who are cared for at home remains at the same level as in 2005; this means a slight drop in the national average in comparison to 2007 (-5\%). In contradistinction to this, the increases in domestic care and in the institutional domain are much more pronounced than in comparison to the base scenario. In Brandenburg and Mecklenburg-Vorpommern, for instance, the number of persons in need of long-term care who need to be in institutional care doubles in 2020 in comparison with 2007. An increase of $61 \%$ is anticipated for Germany as a whole. The city

12 Cf. in particular Blinkert/Gräf (2009), Hackmann/Moog (2008b), as well as Hofmann (2006).

13 Blinkert (2007) moreover shows that domestic care provided by relatives or friends and acquaintances varies considerably from one social group to another. In particular in higher-status groups, the opportunity costs, i.e. foregoing income from gainful employment, play a significant role in selecting whether to care for relatives.

14 The incentive to provide family long-term care is to be increased through the proposal of the Federal Family Ministry to introduce a legal right to family long-term care leave, (cf. Braun/Haas 2010).

${ }^{15}$ A distribution scale was calculated for the distribution of persons in need of long-term care, which is above 979,000 (= number of persons in need of long-term care who were exclusively cared for by relatives in 2005). To this end, the total of persons in need of long-term care in the institutional and domestic domains was set to 100 in each case. The share resulting for institutional and domestic care was then used to distribute persons in need of long-term care among the two forms of professional care who had previously been cared for by relatives. 
Tab. 4: Number of persons in need of long-term care in 2020 by form of care (alternative scenario; absolute figures in 1,000s; change from 2007 to 2020)

\begin{tabular}{|c|c|c|c|c|c|c|c|}
\hline & \multicolumn{2}{|c|}{ At home } & \multicolumn{2}{|c|}{ Domestic care } & \multicolumn{2}{|c|}{ Institutional care } & \multirow[t]{2}{*}{ Total } \\
\hline & absolute & change & absolute & change & absolute & change & \\
\hline Baden-Württemberg & 101 & $-5 \%$ & 84 & $81 \%$ & 135 & $61 \%$ & 320 \\
\hline Bayern & 138 & $-2 \%$ & 110 & $58 \%$ & 169 & $62 \%$ & 417 \\
\hline Berlin & 46 & $0 \%$ & 36 & $58 \%$ & 46 & $68 \%$ & 128 \\
\hline Brandenburg & 34 & $-17 \%$ & 40 & $77 \%$ & 44 & $107 \%$ & 118 \\
\hline Bremen & 9 & $3 \%$ & 8 & $30 \%$ & 8 & $30 \%$ & 24 \\
\hline Hamburg & 15 & $-5 \%$ & 17 & $36 \%$ & 19 & $32 \%$ & 52 \\
\hline Hessen & 89 & $-7 \%$ & 51 & $42 \%$ & 75 & $69 \%$ & 215 \\
\hline Mecklenburg-Vorpommern & 23 & $-13 \%$ & 25 & $78 \%$ & 32 & $91 \%$ & 80 \\
\hline Niedersachsen & 100 & $-7 \%$ & 82 & $47 \%$ & 118 & $49 \%$ & 300 \\
\hline Nordrhein-Westfalen & 212 & $-6 \%$ & 161 & $51 \%$ & 241 & $57 \%$ & 614 \\
\hline Rheinland-Pfalz & 50 & $-5 \%$ & 31 & $58 \%$ & 48 & $63 \%$ & 130 \\
\hline Saarland & 14 & $-2 \%$ & 9 & $53 \%$ & 14 & $53 \%$ & 37 \\
\hline Sachsen & 49 & $-4 \%$ & 53 & $62 \%$ & 67 & $56 \%$ & 170 \\
\hline Sachsen-Anhalt & 35 & $-6 \%$ & 31 & $59 \%$ & 40 & $67 \%$ & 106 \\
\hline Schleswig-Holstein & 31 & $1 \%$ & 26 & $60 \%$ & 47 & $46 \%$ & 104 \\
\hline Thüringen & 33 & $-7 \%$ & 27 & $61 \%$ & 35 & $75 \%$ & 95 \\
\hline Germany & 979 & $-5 \%$ & 792 & $57 \%$ & 1,139 & $61 \%$ & 2,911 \\
\hline
\end{tabular}

Source: own calculations.

states of Bremen ( $+30 \%$ ) and Hamburg (+32\%) do best here. In addition to institutional care, one must also anticipate considerable increases in the domestic care of persons in need of long-term care. A heterogeneous picture also emerges in this case for the individual Federal Länder, from $+42 \%$ in Hessen to $+81 \%$ in BadenWürttemberg (not including the city states). The national German average is a $57 \%$ increase in period from 2007 to 2020.

These two scenarios make it clear in which corridor the number of persons in need of long-term care who need professional care could move in future. In the domestic domain, the number of persons in need of long-term care could be between 646,000 and 792,000 in 2020 . The model calculations for the institutional domain reveal a range from 925,000 to 1.139 million. A comparison of the results of the base scenario with those of the alternative scenario hence makes it clear that there is a high substitution potential between private and professional care which will also ultimately be reflected in the need for professional long-term carers in the future. 


\section{The future demand on the labour market for long-term care: Model} calculations for the Federal Länder to 2020

The future demand for professional long-term carers emerges below from the multiplication of the Land-specific rate of full-time equivalent posts per person in need of long-term care by form of care (domestic long-term care services and institutional accommodation) by the number of persons in need of long-term care in the future. The results of these calculations are shown both for the base scenario and for the alternative scenario. The number of employees in full-time equivalent posts is 728,000 in the base scenario for the entire Federal territory. This corresponds to an increase of $30 \%$ as against 2007. A highly heterogeneous picture emerges for the individual Federal Länder: In Brandenburg and Mecklenburg-Vorpommern the requirement might increase by 48 and $42 \%$, respectively, whilst the increase could be $28 \%$ in the largest Western German large surface-area Länder (NordrheinWestfalen), $32 \%$ (Bayern) and $34 \%$ (Baden-Württemberg). All in all, the requirement in the institutional domain $(+30 \%)$ will increase somewhat more rapidly than in domestic long-term care services $(+28 \%)$. However, there are also differences between the Federal Länder in this respect.

The demand for long-term carers is much higher in the alternative scenario, in which the level of care-giving relatives is fixed at that of 2005. Overall demand could increase by $59 \%$ by 2020; here too demand is growing more rapidly in the institutional domain $(+60 \%)$ than in the domestic domain $(+57 \%)$. A total of roughly 893,000 persons (in full-time equivalent posts) could be employed in long-term care in 2020. The increases over all care forms are largest in the two Eastern German Federal Länder Brandenburg and Mecklenburg-Vorpommern, at +98 and $+88 \%$ respectively. Demand in institutional care, at $+91 \%$ (Mecklenburg-Vorpommern) and $+107 \%$ (Brandenburg), is greater than in domestic care (Mecklenburg-Vorpommern: $+78 \%$, Brandenburg: $+77 \%)$. In some Federal Länder, by contrast, the increase in domestic care is more rapid than in the institutional field; this includes Baden-Württemberg, Sachsen and Schleswig-Holstein.

It has so far been presumed in the base and in the alternative scenarios that the ratio between care staff and persons in need of long-term care remains constant over time. However, it is certainly possible for productivity increases to emerge (= improved ratio of carers/persons in need of long-term care) in the provision of long-term care services in the domestic and institutional domains: on the one hand, by virtue of the increased use of medical-technical aids, and on the other hand through new forms of organisation and procedures in care. In this context, changes in the qualification-specific composition of the care staff (personnel mix) may impact the personnel assessment base. By using more qualified staff, a positive impact can be expected on the ratio of carers/persons in need of long-term care. The requirement of carers per person in need of long-term care could furthermore be reduced by new concepts of living arrangements for persons in need of long-term care. For instance, supervised shared living arrangements (care provided by domestic long-term care services) might bring about favourable developments with 


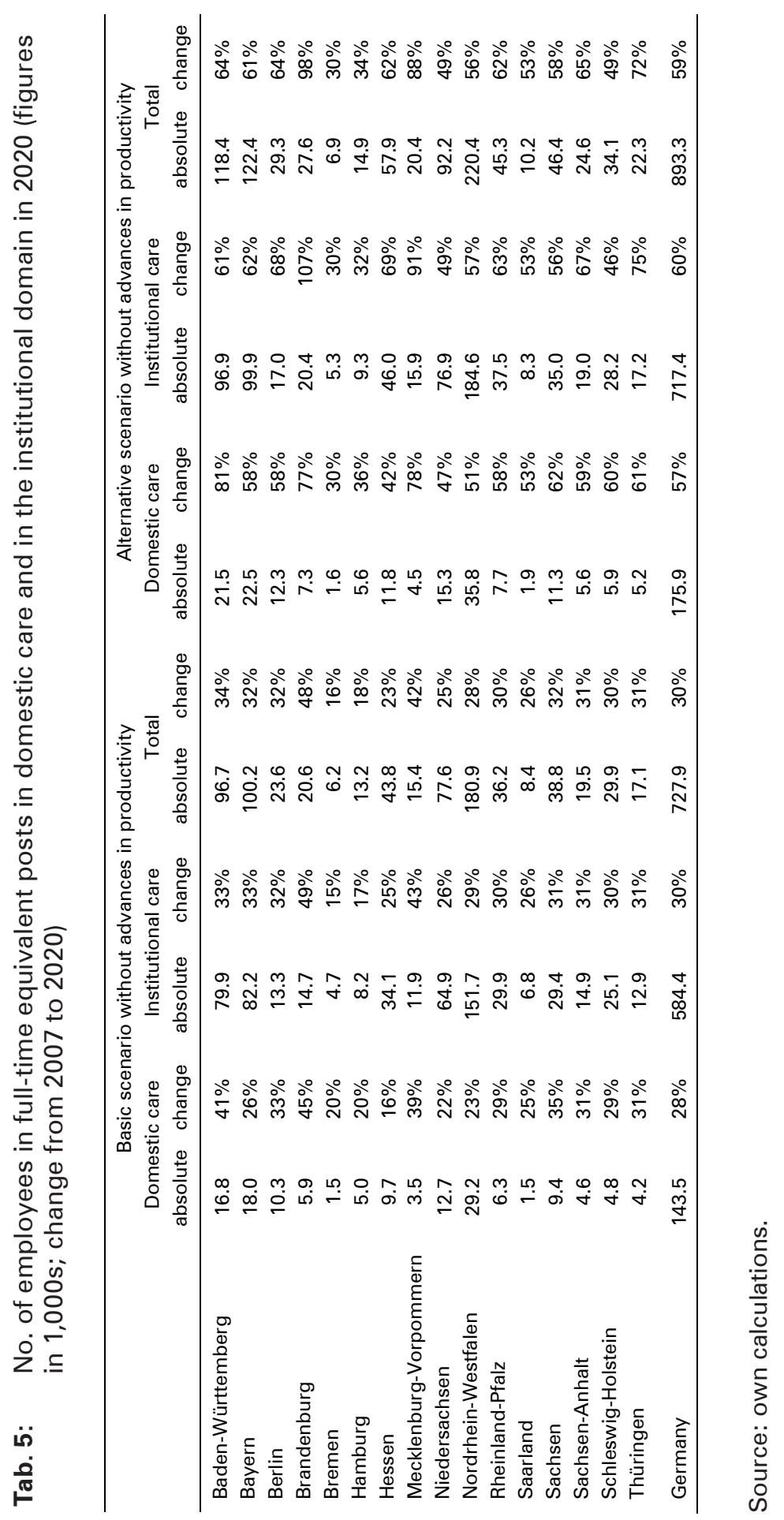


regard to the ratio between carers/persons in need of long-term care (Bartholomeyczik/Hunstein 2000). Domestic long-term care services could then care for more persons in one shift due to persons in need of long-term living together (time saving because of fewer journeys). All these factors, when added up, can lead to productivity advances in long-term care. However, the progress made in productivity in the care domain may be somewhat slight in comparison with other branches of industry because of the largely labour-intensive activities (Advisory Council on the Assessment of Developments in the Health Care System/Sachverständigenrat zur Begutachtung der Entwicklung im Gesundheitswesen 2009).

Advances in productivity amounting to $0.25 \%$ p.a. are expected to occur in both types of care, for the base scenario as well as for the alternative scenario, so that, in the final analysis, the ratio between staff deployed and persons in need of long-term care is improved (cf. on this also Ernste/Pimpertz 2008). The demand for long-term carers in 2020 is now roughly 705,000 full-time equivalent posts in the base scenario - these are 23,000 fewer employees than in the scenario without productivity advances (cf. Tab. 6). The productivity advances, which are already presumed to be slight, consequently lead to a lower demand for staff. In the alternative scenario, the demand in Germany totals 865,000 full-time equivalent posts in 2020 - coming to roughly 28,000 fewer employees than in the alternative scenario without productivity advances. This makes it clear that gains in efficiency may at least reduce the demand for long-term carers somewhat. A decisive role in the future development of the professional labour market for long-term care has however been played by the commitment of care-giving relatives, as documented in the comparisons between the base and alternative scenarios.

All in all, the results from the individual variants differ widely because of the underlying presumptions. In the most favourable case, that is assuming that more relatives will take care of persons in need of long-term care in the future, the demand for institutional care increases by 115,000 additional full-time equivalent posts by 2020 . The increase in absolute terms would be 27,000 full-time equivalent posts in the domestic domain. A comparison with other studies, which however relate to the total German labour market for long-term care, makes it clear that the results for the individual Federal Länder are highly plausible in the aggregate. Augurzky et al. (2009) reach an increase in demand in their calculations amounting to almost 80,000 carers by 2020 for the institutional and domestic domains. Having said that, these calculations relate only to carers, whilst this essay covers all employees in the care domain, i.e. both specialist carers and technical and administrative staff are taken into account. The Cologne Institute for Economic Research (Institut der deutschen Wirtschaft - IW) also reaches similar conclusions in its survey of Germany as a whole: In the variant without productivity advances, there will be roughly 900,000 full-time jobs in 2020 according to the Institute (cf. Ernste/Pimpertz 2008). Schnabel (2007) calculates almost 830,000 full-time equivalent posts in 2020. The comparable alternative scenario without productivity advances (cf. Tab. 5) shows roughly 893,000 full-time equivalent posts for 2020.

The model calculations which have been carried out for the Federal Länder are to make it clear to what degree the development of the professional labour market for 


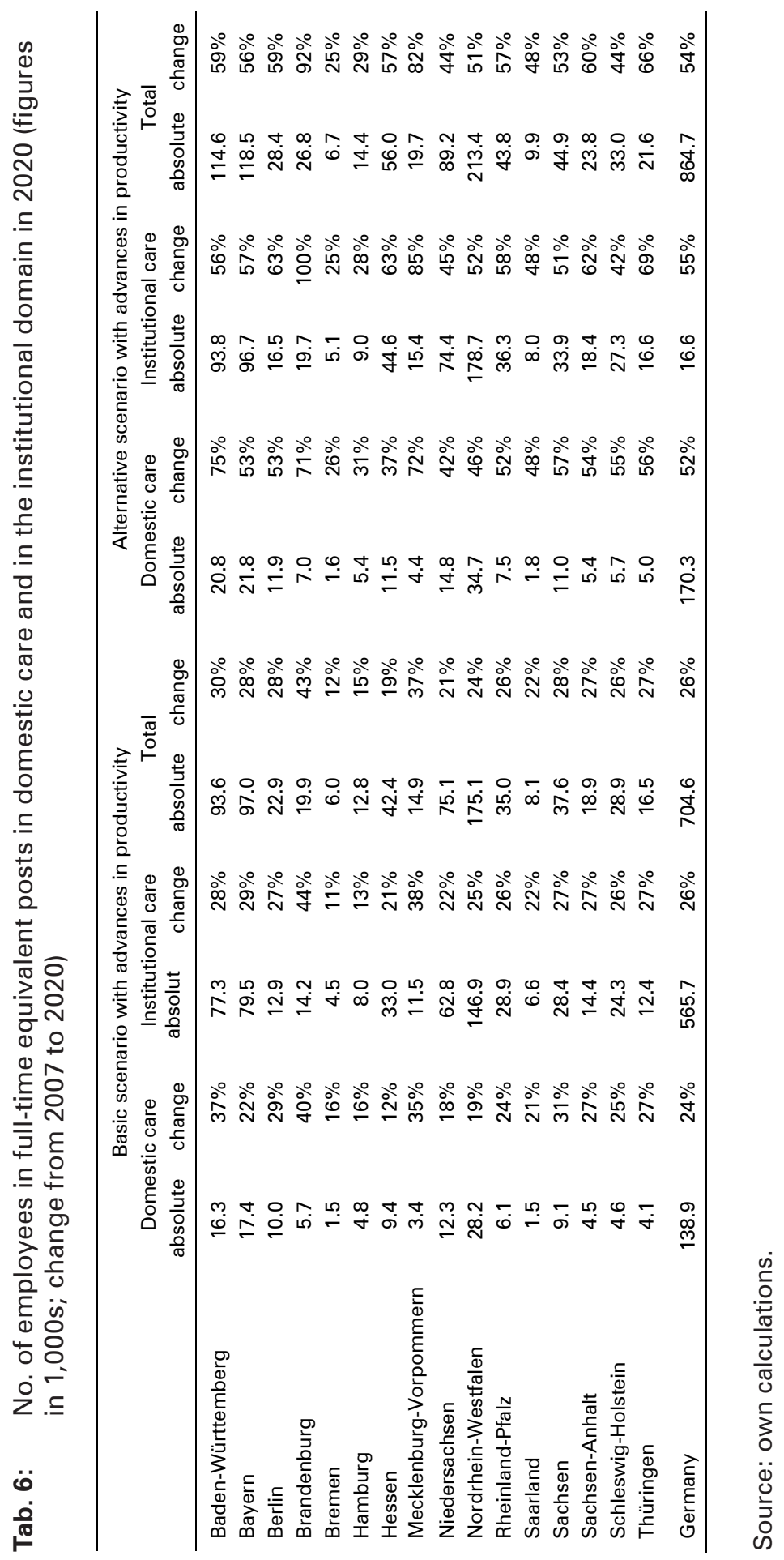


long-term care depends on the commitment of care-giving relatives and on productivity advances. There is no doubt that, on the demand side, the (future) costs for accommodation in institutional facilities and/or for the employment of domestic longterm care services play a major role in this context. On the supply side, work income is an important determinant in opting for or against working in care. This is likely to also play a role in the development of the family care potential, since in addition to moral aspects (care of the parents, of the partner) monetary factors (comparison of the income for the care of relatives with regular gainful employment) are also significant. The development of the informal and professional labour markets for long-term care in Germany will however also depend on the employment of foreign domestic help, since such individuals have recently been permitted to carry out basic long-term care activities legally (cf. Bundesagentur für Arbeit 2010), so that a further alternative to care of persons in need of long-term care has emerged. Relatives of persons in need of long-term care are now faced with the decision of taking on care themselves, using domestic long-term care services, arranging placement in an institutional long-term care home or availing themselves of (foreign) domestic help. Since the employment of foreign domestic help is frequently the cheapest alternative for care of a person in need of long-term care - in particular if it is timeintensive care - this form of (legal or illegal) employment is likely to continue to gain importance in the near future. This development is favoured by the predicted increase in the incidence of dementia, since 24 -hour care is frequently necessary in such cases. Since the statutory framework can change over time and this may exert a considerable influence on the selection of the care arrangement, these incentive mechanisms were however deliberately disregarded.

Care has very recently become the focus of greater political awareness, so that the incentives for taking up work in the care domain could change as a result of new legal initiatives. Firstly, there will be a minimum wage for employees from mid-2010 onwards, coming to EUR 8.50 in Western Germany and EUR 7.50 in Eastern Germany. The impact of this sector-specific minimum wage on the supply of labour cannot be clearly determined a priori since interdependences exist between the labour market for long-term care and other sectors (and also illegal employment). These mutual relationships admittedly depend not only on the framework in care, but also on the conditions in the other labour market segments (working hours, wages, professional outlook, etc.) which may also still change over time. Secondly, the introduction of family leave is being discussed at present (cf. Braun/Haas 2010). The introduction of the Long-term Care Leave Act (Pflegezeitgesetz) as early as 2008 has provided a legal right vis-à-vis employers (under certain preconditions) for employees who care for close relatives. However, such long-term care is restricted to a maximum of six months. The proposal of the Federal Family Minister provides for a legal entitlement to two years' long-term care leave in which half of the working hours are to be worked but three-quarters of the salary drawn. When long-term care leave ends, full-time employment is provided for, in which three-quarters of the salary is also earned until the wage and salary account is balanced. Since care by relatives is cheaper than accommodation in a long-term care home, it is hoped that the Act will reduce the burdens on the institutions funding long-term care. However, 
industry has voiced reservations since this arrangement would oblige enterprises to advance payment for two years and risk an employee not returning to the enterprise after long-term care leave.

\section{Conclusion}

As a result of demographic change, there will be more and more elderly people in future, whilst the working-age population shrinks in size. Since the probability of requiring long-term care is strongly correlated with age, a marked increase in the number of persons in need of long-term care is anticipated in Germany. All in all, the number of persons in need of long-term care could increase from its current level of 2.25 million to 2.9 million by 2020 . Having said that, the development between the individual Federal Länder is highly heterogeneous in some cases because of the different age structures. The population has been observed to shrink and age for several years in the Eastern German Federal Länder, whilst the fall in the population size has only recently set in in the Western Federal Länder. Thus, a relatively larger number of more persons in need of long-term care will live in Eastern Germany in future than in Western Germany. Professional care will gain further significance in general terms as the number of persons in need of long-term care increases, since the family care potential is decreasing. Because of increasing care provided by domestic long-term care services and accommodation in long-term care homes, the demand for professional care staff will increase considerably. The model calculations show that the number of staff could increase from today's level of roughly 561,000 (in full-time equivalent posts) between 700,000 and 900,000 in 2020. The very wide range in the results has made it clear that the development of the demand for professional carers in particular depends on the future commitment of caregiving relatives, as well as on productivity increases in the provision of long-term care services. Over and above this, the increasing demand for professional care should also be met by a corresponding supply of workers to create an employment effect. To this end, on the one hand the long-term care services must be affordable for persons in need of long-term care and their relatives. On the other hand, the possibilities to earn a living on the labour market for long-term care must be sufficiently high, so that more persons in gainful employment will opt for a caring profession.

I would like to thank two anonymous reviewers for valuable pointers and comments. Furthermore, I would like to thank those who attended the "International Conference on Evidence-based Policy in Long-term Care" at the London School of Economics (LSE), 8-11 September 2010, for their helpful comments. 


\section{References}

Augurzky, Boris et al., 2009: Auswirkungen von Mindestlöhnen auf Pflegeeinrichtungen und Pflegebedürftige. Auszug aus dem Pflegeheim Rating Report 2009. RheinischWestfälisches Institut für Wirtschaftsforschung, ADMED GmbH Unternehmensberatung Health Care, Institute for Health Care Business GmbH (HCB): Essen

Bartholomeyczik, Sabine; Hunstein, Dirk, 2000: Erforderliche Pflege - zu den Grundlagen einer Personalbemessung. Pflege \& Gesellschaft 5,4: 105-109

Blinkert, Baldo, 2007: Bedarf und Chancen: Die Versorgungssituation pflegebedürftiger Menschen im Prozess des demografischen und sozialen Wandels. In: Pflege \& Gesellschaft 12,3: 227-239

Blinkert, Baldo; Gräf, Bernhard, 2009: Deutsche Pflegeversicherung vor massiven Herausforderungen. Frankfurt: Deutsche Bank Research

Braun, Stefan; Haas, Sibylle, 2010: Familien-Pflegezeit. Ein Angebot mit Charme. In: Süddeutsche Zeitung. URL: http://www.sueddeutsche.de/politik/743/504950/text, 8.3.2010

Bundesagentur für Arbeit (Eds.), 2010: Vermittlung von Haushaltshilfen in Haushalte mit Pflegebedürftigen nach Deutschland, Zentral Auslands- und Fachvermittlung (ZAV). Bonn

Bundesministerium für Gesundheit, 2010: Pflege-Tüv. URL: http://www.bmg.bund.de/ SharedDocs/Standardartikel/DE/AZ/P/Glossarbegriff-Pflege-Tuev.html, 25.03.2010

Creutzburg, Dietrich, 2010: Mindestlöhne sind auf dem Vormarsch. In: Handelsblatt 26.3.2010: 16-17

Enste, Dominik; Pimpertz, Jochen, 2008: Wertschöpfungs- und Beschäftigungspotenziale auf dem Pflegemarkt in Deutschland bis 2050. Köln: Institut der deutschen Wirtschaft (IW)

Hackmann, Tobias; Moog, Stefan, 2008a: Älter gleich kränker? Auswirkungen des Zugewinns an Lebenserwartung auf die Pflegewahrscheinlichkeit. Diskussionsbeiträge 26. Freiburg: Forschungszentrum Generationenverträge

Hackmann, Tobias; Moog, Stefan, 2008b: Pflege im Spannungsfeld von Angebot und Nachfrage. Diskussionsbeiträge 33. Freiburg: Forschungszentrum Generationenverträge

Hofmann, Herbert, 2006: Altenpflege und soziale Dienste - wachsender Bedarf bei fehlenden Mitteln. ifo Schnelldienst 59,15: 24-30

Keck, Wolfgang; Saraceno, Chiara, 2009: Balancing elderly care and employment in Germany. Discussion Paper 2009-401. Berlin: WZB

Konrad, Kai et al., 2002: Geography of the family. In: American Economic Review 92: 981-998

Neuhaus, Andrea et al., 2009: Situation und Bedarf von Familien mit mittel- und osteuropäischen Haushaltshilfen. Köln: Deutsches Institut für angewandte Pflegeforschung e.V.

Sachverständigenrat zur Begutachtung der Entwicklung im Gesundheitswesen, 2009: Koordination und Integration - Gesundheitsversorgung in einer Gesellschaft des längeren Lebens, Sondergutachten. Bonn

Schnabel, Reinhold, 2007: Zukunft der Pflege. Köln: Initiative Neue Soziale Marktwirtschaft (INSM) 
Statistische Ämter des Bundes und der Länder (Eds.), 2008: Demografischer Wandel in Deutschland: Auswirkungen auf Krankenhausbehandlungen und Pflegebedürftige im Bund und in den Ländern 2. Wiesbaden

Statistisches Bundesamt (Eds.), 2006: Bevölkerung Deutschlands bis 2050: 11. koordinierte Bevölkerungsvorausberechnung. Wiesbaden

Statistisches Bundesamt (Eds.), 2008: Pflegestatistik 2007: Pflege im Rahmen der Pflegeversicherung. Deutschlandergebnisse. Wiesbaden

Statistisches Bundesamt (Eds.), 2009: Bevölkerung Deutschlands bis 2060: 12. koordinierte Bevölkerungsvorausberechnung. Wiesbaden

Translated from the original text by the Federal Institute for Population Research, for information only. The authorised original article in German is available under the title "Der zukünftige Bedarf an Pflegearbeitskräften in Deutschland: Modellrechnungen für die Bundesländer bis zum Jahr 2020", DOI 10.4232/10.CPoS-2010-09de or URN urn:nbn:de:bib-cpos-2010-09de8, at http://www. comparativepopulationstudies. de.

Dr. Carsten Pohl $(\triangle)$. Institut für Arbeitsmarkt- und Berufsforschung (IAB), Regionales Forschungsnetz, IAB Nordrhein-Westfalen, 40474 Düsseldorf, Germany.

E-Mail: carsten.pohl@iab.de 


\section{Comparative Population Studies - Zeitschrift für Bevölkerungswissenschaft}

wWw.comparativepopulationstudies.de

ISSN: 1869-8980 (Print) - 1869-8999 (Internet)

Published by / Herausgegeben von

Prof. Dr. Norbert F. Schneider

Layout and print: Federal Institute for Population Research, Wiesbaden

(Germany)

\section{Managing Editor / Redaktion}

Frank Swiaczny

Copy Editor / Schlußredaktion

Dr. Evelyn Grünheid

\section{Scientific Advisory Board / \\ Wissenschaftlicher Beirat}

Jürgen Dorbritz (Wiesbaden)

Paul Gans (Mannheim)

Johannes Huinink (Bremen)

Dirk J. van de Kaa (Den Haag)

Marc Luy (Wien)

Notburga Ott (Bochum)

Peter Preisendörfer (Mainz)

\section{Board of Reviewers / Gutachterbeirat}

Martin Abraham (Erlangen)

Laura Bernardi (Lausanne)

Hansjörg Bucher (Bonn)

Claudia Diehl (Göttingen)

Andreas Diekmann (Zürich)

Gabriele Doblhammer-Reiter (Rostock)

Henriette Engelhardt-Wölfler (Bamberg)

E.-Jürgen Flöthmann (Bielefeld)

Alexia Fürnkranz-Prskawetz (Wien)

Beat Fux (Zürich)

Joshua Goldstein (Rostock)

Karsten Hank (Mannheim)

Sonja Haug (Regensburg)

Franz-Josef Kemper (Berlin)

Hans-Peter Kohler (Philadelphia)

Michaela Kreyenfeld (Rostock)

Aart C. Liefbroer (Den Haag)

Kurt Lüscher (Konstanz)

Dimiter Philipov (Wien)

Tomáš Sobotka (Wien)

Heike Trappe (Rostock) 